\title{
CLAY MINERALOGY OF THE SEDIMENTARY IRON-NICKEL ORE OF AGIOS IOANNIS, NE BOEOTIA: NEW DATA AND IMPLICATION FOR DIAGENETIC MODIFICATIONS
}

\author{
Christidis G.E. ${ }^{1}$, and Skarpelis. N. ${ }^{2}$ \\ ${ }^{1}$ Technical University of Crete, Department of Mineral Resources Engineering, 73100 Chania, Greece, \\ christid@mred.tuc.gr \\ ${ }^{2}$ University of Athens, Department of Geology, 15787 Panepistimioupolis Ano Ilissia, Athens, Greece, \\ skarpelis@geol.uoa.gr
}

\begin{abstract}
The clay mineralogy of the sedimentary Fe-Ni deposit of Agios Ioannis and a Ni-lateritic profile from Pavlos, both in Lokris area, Greece, is investigated. The clay fraction of samples from Agios Ioannis consists mainly of Fe-rich chlorite and Fe-smectite, with minor serpentine, hematite and goethite. Locally, disordered talc (kerolite and/or pimelite), illite, R1 mixed layer illite/smectite and gibbsite are identified. The lateritic profile has different composition and contains mainly Fe-rich smectite (nontronite and/or ferruginous montmorillonite) with minor serpentine, goethite, magnetite, and talc, whereas chlorite is absent. It is suggested that in the Agios Ioannis deposit chlorite has formed from smectite via R0 mixed layer chlorite/smectite with $>80 \%$ chlorite layers. The source of Al is probably the diagenetic transformation of pedogenic goethite to hematite during burial. The lack of chlorite in the lateritic profile of Pavlos is attributed to the limited presence of goethite. Smectite is believed to be a major mineralogical constituent of the Fe-Ni ores of the broader Lokris area.
\end{abstract}

Key words: Fe-Ni deposit, Ni-lateritic profile, Fe-smectite, Fe-chlorite, diagenesis, Agios Ioannis, NE Boeotia.

\section{Introduction}

The Upper Cretaceous Fe-Ni sedimentary deposits of Lokris, have been studied thoroughly over the last 60 years. It is well established that the principal Ni-bearing phases are phyllosilicates, mainly chlorite (Ni-chamosite and nimite), talc serpentine (antigorite and nepouite) and garnierite (Augoustithis 1962; Siegl, 1954; Albandakis, 1974; 1984; Rosenberg, 1984; Valeton et al., 1987; Alevizos, 1997; Skarpelis, 1997; 1999; 2000; Eliopoulos \& Economou-Eliopoulos, 2000; Apostolikas, 2007). Albandakis $(1974 ; 1984)$ reported the presence of Ni-montmorillonite in the deposit of Agios Ioannis and Maksimovic et al. (1993) found smectite in the Marmeiko deposit. Alevizos (1997) and Apostolikas (2007) reported clinochlore in the deposits of Agios Ioannis and Kopais. Ni-free clay minerals such as kaolinite have been reported in the deposits of Agios Ioannis and Marmeiko (Maksimovic et al., 1993; Alevizos, 1997). Similar assemblages of Ni-bearing phyllosilicates have been recorded in the Fe-Ni deposits of Evia (Andoniades \& Vgenopoulos, 1989).

Reactions between clay minerals have been widely used as tracers for mineralogical transformations during diagenesis. The most commonly studied diagenetic change is the smectite to illite tran- 


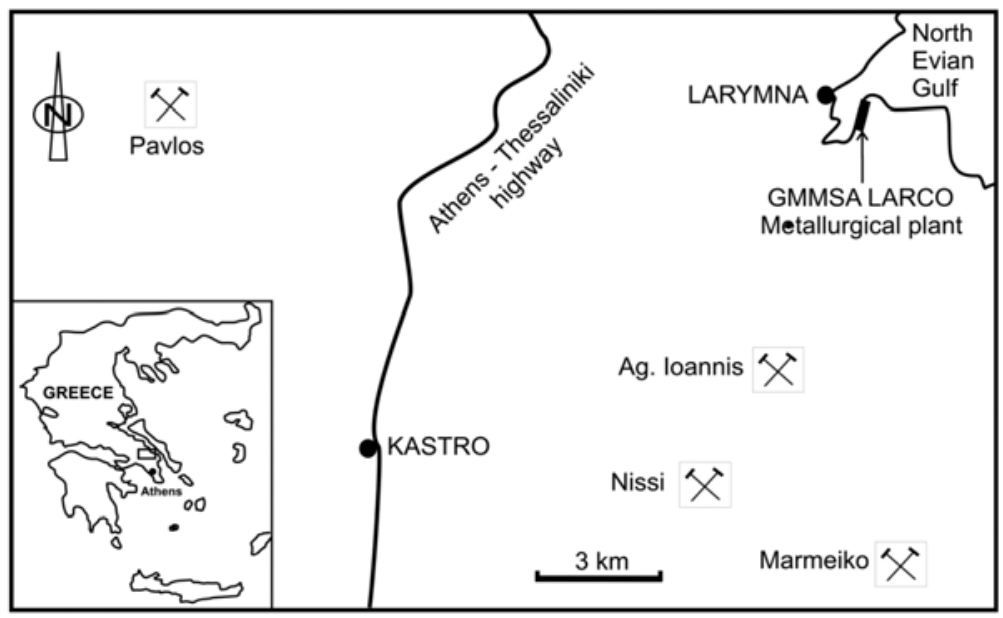

Fig. 1: Location of the lateritic profile at Pavlos and the Fe-Ni ore deposits at Agios Ioannis, NE Boeotia.

sition via mixed-layer illite/smectite (I/S), which has been studied in several sedimentary basins in the world including among others the Gulf Coast (Hower et al., 1976; McCarty et al., 2008 among many others) and several basins in Eastern Europe (Srodon \& Clauer, 2001; Srodon et al., 2006). In contrast, there are fewer references on the smectite to chlorite transition via formation of corrensite. A typical example of this transition is observed in off-shore Brazilian sediments (Chang et al., 1986).

Although the main Ni-phases present in the sedimentary Fe-Ni deposits of Lokris are clay minerals, systematic clay mineralogical study has not been carried out so far. Such a study would be important not only from the pure mineralogical point of view, but it would also shed light on the diagenetic processes that have taken place in the Fe-Ni ores. So far only in a limited number of studies the clay minerals have been distinguished into clastic and authigenic (Valeton et al., 1987). It is the purpose of this preliminary contribution to present the first systematic study of the clay mineralogy of the Agios Ioannis Fe-Ni ore deposit, to compare with the mineralogy of the saprolitic and clayey horizons of a Ni-laterite profile and to propose possible diagenetic modifications of the $\mathrm{Fe}$ Ni sediments.

\section{Geological setting}

Remnants of old weathering crusts on ophiolitic ultramafic rocks are preserved in Lokris area, being a critical lithology, with significance for interpretation of the geological evolution of the ophiolites and the Sub-Pelagonian Belt. They provide evidence on the nature and extent of lateritization processes in pre-Cenomanian - Turonian times. The crusts show large variations in thickness and continuity, mineralogy and chemistry of individual zones. The following lateritic zones are identified (bottom to top) (Skarpelis, 2005): a. Bedrock, b. Saprolite, c. Clayey zone, d. In situ limonite (oxidic zone). Silcrete layers were formed into the clay and goethitic zones. Reworked granular Fe$\mathrm{Ni}$ ore with angular fragments of silcrete overly the lateritic profiles. The uppermost gravelly ferruginous sector, the clayey and goethitic zones, the silcretes and the saprolite were eroded to a major extend and the material reworked and redeposited partly on the bedrock and the lateritic crusts or washed down, transported and redeposited under submarine conditions within mechanical traps on karstified carbonates, forming sedimentary Fe-Ni ore deposits. This is evidenced by the occurrence 
into the sedimentary ore of detrital minerals and particles, identical to typical lateritic weathering crusts (e.g. detrital Cr-spinel, chromite, Ti-oxides, magnetite, maghemite, nickeliferous chlorite, ferruginous spheroidal particles, detritus of silcrete (Skarpelis, 1999 and references therein). Both the weathering crusts and the karstic Fe-Ni deposits were transgressively covered by Upper Cretaceous (Cenomanian-Turonian) limestones.

\section{Sampling and experimental methods}

Fifteen samples were collected from the Agios Ioannis sedimentary Fe-Ni deposit and the lateritic profile close to Pavlos village (Fig. 1). Samples collected from the Agios Ioannis deposit belong to fine-grained (argillaceous) Fe-Ni ore type and were collected from the lowermost part of the underground working face of the deposit, close to the contact with the underlying Jurassic limestones. Samples do not represent profiles but were collected randomly, because systematic diagenetic changes in clay minerals due to burial are not expected in the limited thickness of the deposit (4-7 $\mathrm{m})$. In the lateritic profile of Pavlos samples were collected from the saprolite zone and the clayey (nontronitic) zone.

The bulk mineralogy was determined by X-ray powder diffraction (PXRD) (Siemens D500, CuKa radiation, graphite monochromator, $35 \mathrm{kV}$ and $35 \mathrm{~mA}$, using a $0.02^{\circ}$ step size and 1 second per step counting time), on randomly oriented samples initially crushed with a fly press and subsequently ground with pestle and mortar. The clay mineralogy was determined in materials dispersed in distilled water using an ultrasonic probe (20 seconds). The less than $2 \mu \mathrm{m}$ fractions were separated by settling, dried on glass slides at room temperature and then were solvated with ethylene-glycol vapour at $60^{\circ} \mathrm{C}$ overnight to ensure maximum saturation. XRD traces of the clay fractions, both airdried and after ethylene glycol salvation, were obtained using a $0.02^{\circ}$ step size and 4 seconds per step counting time. The FWHM of the 002 diffraction maximum of chlorite was determined in those clay fractions which did not contain serpentine.

Infrared (IR) spectra of clay fractions from the Pavlos lateritic profile were obtained using a Perkin Elmer 1000 Fourier Transform Infrared (FTIR) spectrometer in the range $400-4000 \mathrm{~cm}^{-1}$. Each spectrum was the average of 50 scans collected at $4 \mathrm{~cm}^{-1}$ resolution. An amount of $1.5 \mathrm{mg}$ of the smectite clay fractions was diluted in $200 \mathrm{mg} \mathrm{KBr}$ and pressed in $13 \mathrm{~mm} \mathrm{KBr}$ disks, which were subsequently dried at $150^{\circ} \mathrm{C}$.

\section{Results}

The argillaceous samples from Agios Ioannis deposit consist of hematite, goethite, quartz, calcite, chlorite, serpentine and talc. Locally, gibbsite and gypsum have been identified. In the random oriented samples the presence of smectite is not unambiguous, because the 001 diffraction maximum coincides with that of chlorite. The samples from Pavlos lateritic profile consist of hematite, dioctahedral smectite, calcite, quartz, serpentine, talc, goethite and magnetite. Representative XRD trace of ethylene-glycol solvated clay fraction from the nontronite zone of the Pavlos lateritic profile is shown in Figure 2. The main phase is smectite associated with minor talc, serpentine and goethite, whereas chlorite is absent. Nevertheless, chlorite has been described in other lateritic profiles in the broader area (Skarpelis, 2000). The mineralogical composition of the nontronite zone is relatively homogeneous. Identical XRD traces were obtained from clay fractions in the saprolite zone (not shown). The rational sequence of the higher order basal reflections indicates that mixed-layering is not present. 


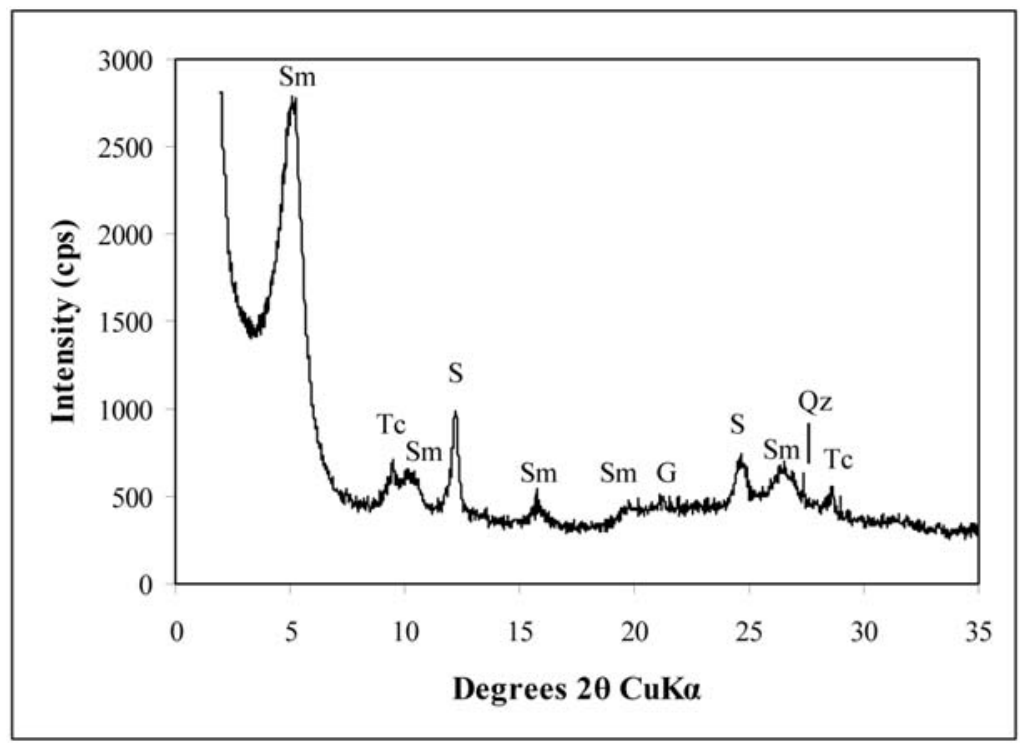

Fig. 2: Glycolated XRD trace of clay fraction from the nontronite zone, Pavlos lateritic profile. Sm= smectite, $\mathrm{S}=$ serpentine, $\mathrm{Tc}=$ talc, $\mathrm{G}=$ goethite, $\mathrm{Qz}=$ quartz.
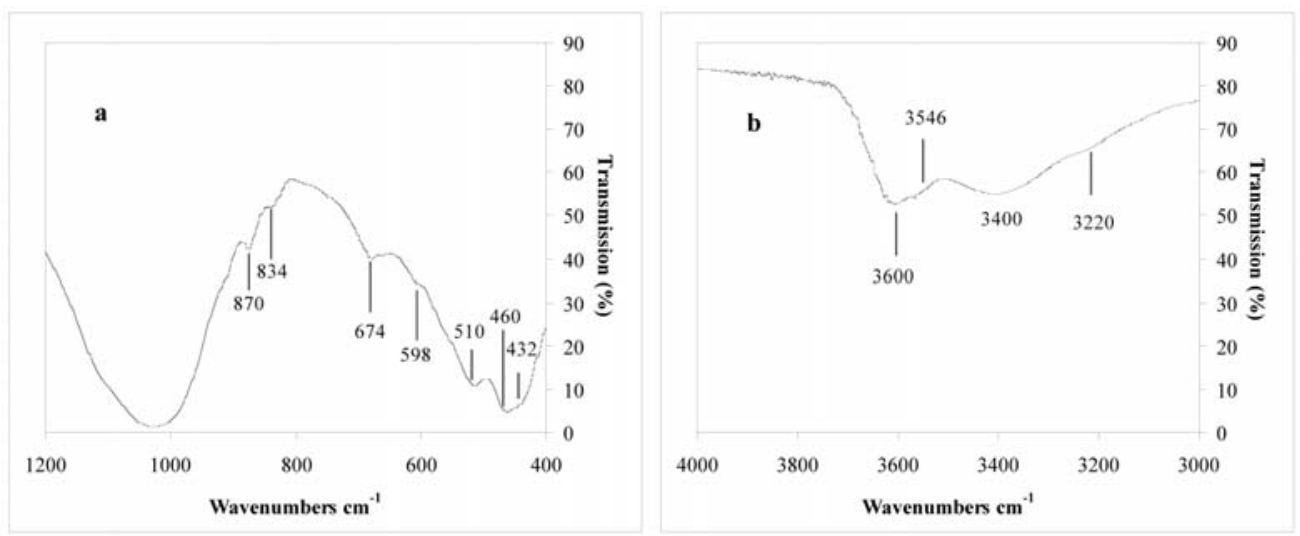

Fig. 3: FTIR spectrum of the smectite from the nontronite zone, Pavlos lateritic profile. a) lattice vibrations, b) $-\mathrm{OH}$ stretching vibrations.

The FTIR spectrum of the smectite from the nontronite zone is shown in Figure 3. The spectrum is typical for Fe-rich smectites. The presence of the bands at $870 \mathrm{~cm}^{-1}$ and $3600 \mathrm{~cm}^{-1}$ (AlFeOH deformation and stretching vibrations respectively) (Fig. 3a), suggests that the smectite may not be true nontronite but ferruginous montmorillonite (Gates, 2005). Nevertheless, the shoulder at $3546 \mathrm{~cm}^{-1}$ is indicative of $\mathrm{Fe}_{2}{ }^{3+} \mathrm{OH}$ linkages. Allocation of the band at $674 \mathrm{~cm}^{-1}$, which could suggest the presence of nontronite, is not unequivocal, because except for Fe-rich dioctahedral smectites, trioctahedral minerals like talc and serpentine, which are present in the sample (Fig. 2), have also their main 

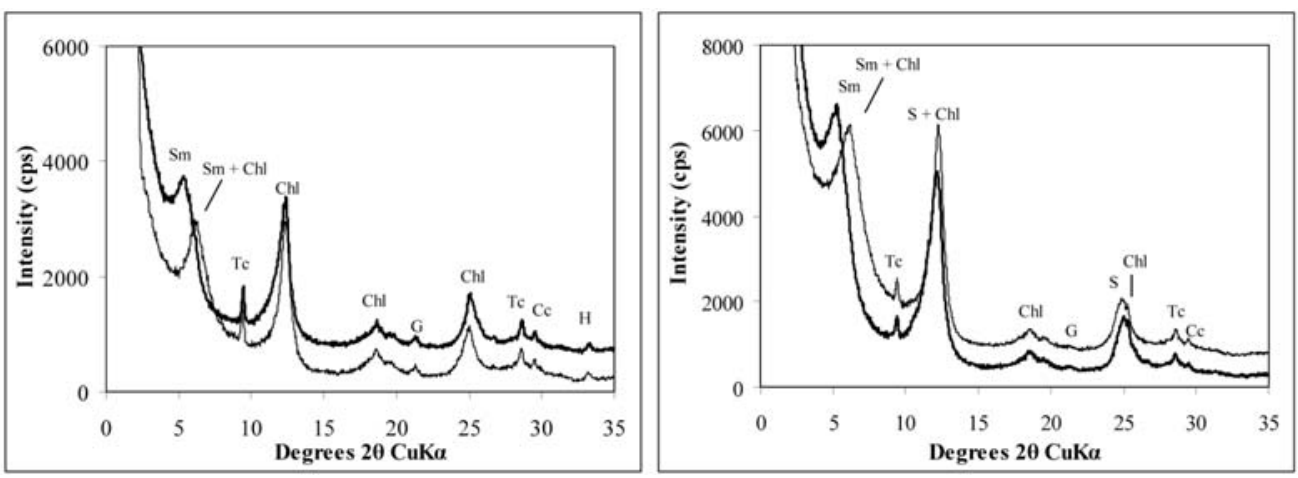

Fig. 4: XRD traces of clay fractions of representative samples from the Agios Ioannis deposit. $\mathrm{Sm}=$ smectite, $\mathrm{Tc}=$ talc, $\mathrm{Chl}=$ chlorite, $\mathrm{S}=$ serpentine, $\mathrm{G}=$ goethite, $\mathrm{H}=$ hematite, $\mathrm{Cc}=$ calcite.

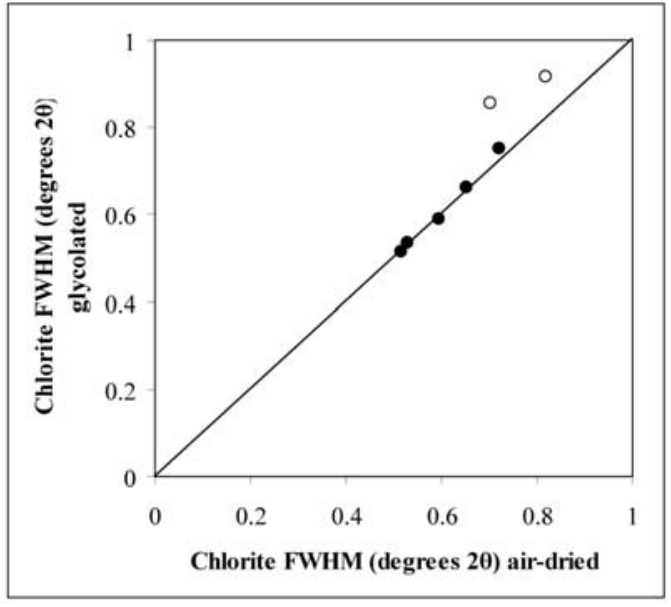

Fig. 5: FWHM of chlorites in ethylene glycol solvated and air-dried clay fractions. Open circles denote samples in which the FWHM of the ethylene glycol solvated samples is significantly greater than the air-dried samples.

$\mathrm{M}_{3} \mathrm{OH}$ deformation band in the same area. In the Fe-rich dioctahedral smectites the M-O deformation band at $674 \mathrm{~cm}^{-1}$ suggests that at least $75 \%$ of the octahedral cations are $\mathrm{Fe}^{3+}$. Note that some of the spectra (not shown here) strongly suggest the presence of nontronite. In any case the results suggest that the smectite present in this sample is a Fe-rich smectite.

Representative XRD traces of clay fractions of samples from Agios Ioannis deposit are shown in Fig. 4. Opposite to the lateritic profile chlorite is the most abundant phase. Nevertheless, most samples are rich in smectite, as it is verified by the shift of the 001 diffraction maximum after exposure in ethylene-glycol vapour. Serpentine, talc and calcite are also present. Finally, goethite and hematite are observed in most of the clay fractions examined. From the relative intensities of the basal reflections it is suggested that chlorite is Fe-rich (odd-order diffraction maxima have considerably lower intensity than even-order diffraction maxima).

In most samples the full width at half maximum (FWHM) of chlorites in the ethylene-glycol solvated clay fractions is comparable to that of the air-dried samples (Fig. 5). In two exceptions the ethyleneglycol solvated samples have greater FWHM (the observed difference is statistically significant) 


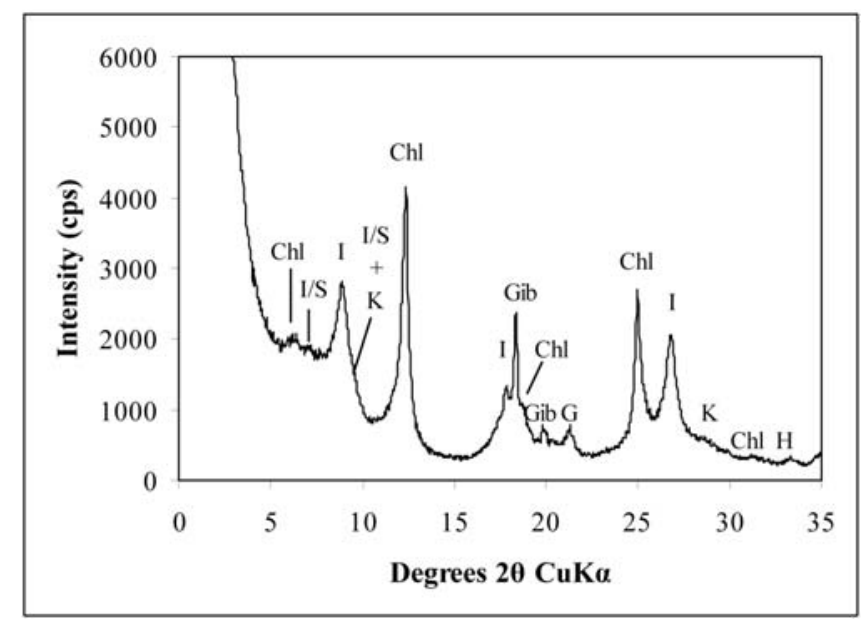

Fig. 6: Illite-gibbsite bearing ethylene glycol solvated clay fraction from the Agios Ioannis Fe-Ni deposit. I= illite, $\mathrm{I} / \mathrm{S}=\mathrm{R} 1$ mixed layer illite smectite, $\mathrm{K}=$ kerolite, $\mathrm{Chl}=$ chlorite, $\mathrm{Gib}=$ gibbsite, $\mathrm{G}=$ goethite, $\mathrm{H}=$ hematite.

and the diffraction maximum of the 002 maximum shifts to lower angles (i.e. higher d-spacings), suggesting random interstratification (R0) with smectite. In these clay fractions the proportion of smectite in the mixed layer phase does not exceed 20\% (Moore \& Reynolds, 1997).

Locally, the Agios Ioannis deposit has unusual mineralogical composition and contains also illite, R1 mixed layer illite/smectite, gibbsite and disordered talc (Fig. 6). These samples are smectitefree. Note the differences in talc between the samples from the lateritic profile and those from Agios Ioannis deposit. The former is well crystallized, whereas the latter is disordered. It is thus considered that the talc from Agios Ioannis is kerolite or/and pimelite. Also, the distribution of peak heights of the basal reflections indicates that illite is Al-rich. Had Fe-rich illite been present then the ratio of the odd/even basal diffraction maxima would have been higher than the $\mathrm{Al}$ rich illite. Based on the XRD traces the illite-gibbsite bearing samples are rich in $\mathrm{Al}$.

\section{Interpretation and discussion}

The lateritic profile in Pavlos has significantly different mineralogical composition from the clayey sector of the sedimentary Fe-Ni deposit at Agios Ioannis. The main difference is the predominance of Fe-rich smectite (ferruginous montmorillonite and nontronite) in the former compared to Fe-rich chlorite present in the Fe-Ni deposit. Other important difference is the presence of well crystallized talc in the lateritic profile and kerolite/pimelite and Al-rich minerals (except for chlorite), such as gibbsite, illite and mixed layer illite/smectite (I/S) in the clayey ore. Considering that the weathering of lateritic profiles was the source for the Fe-Ni ores (Skarpelis, 1999), it follows that the observed differences reflect diagenetic modifications or/and additional sources.

An important finding of this contribution is that the clayey Fe-Ni ore contains abundant smectite. The significance of smectite as a critical diagenetic mineral had not been understood and recognized in previous studies, since they were focused mainly on issues on the origin and geochemistry of the ores. Convincing evidence for the presence of smectite has been presented only in Marmeiko deposit (Maksimovic et al., 1993). Moreover the shift from Fe-smectite as main phase in the lateritic profile to Fe-chlorite which is a main phase in the Fe-Ni ore, suggests conversion of smectite to 
chlorite after deposition. Diagenetic transformation of smectite to chlorite via intermediate corrensite has been reported in marine sediments off-shore Brazil (Chang et al., 1986). Evidence for this diagenetic transformation in the $\mathrm{Fe}-\mathrm{Ni}$ deposit of Agios Ioannis is provided by the R0 mixed layer chlorite/smectite (Fig. 5).

Nevertheless, it is surprising that this transformation did not take place in the Fe-smectite of the lateritic profiles. Different depth of burial does not seem to be the main reason for this difference, because the whole area has similar geological evolution. The difference in altitude between the lateritic profiles and the mechanical traps on Jurassic limestones where the laterite-derived material was deposited, does not exceed 200-500 m. Moreover after the Cenomanian-Turonian transgression both areas had the same burial history. It is expected that maximum depth of burial did not exceed 1500$2000 \mathrm{~m}$ after deposition of the Upper Cretaceous limestones and the Paleocene flysch. Diagenetic conversion of smectite to chlorite requires temperatures in excess of $150^{\circ} \mathrm{C}$ (Chamley, 1989), which certainly were not experienced in this area. Similarly, the presence of R1 mixed layer I/S suggests temperatures of $100-110^{\circ} \mathrm{C}$. Considering a maximum burial depth of $\sim 2000 \mathrm{~m}$, average surface temperature of $20^{\circ} \mathrm{C}$ and geothermal gradient $25-30^{\circ} \mathrm{C}$ per $\mathrm{km}$ of burial, the temperature at maximum burial depth should not exceed $70-80^{\circ} \mathrm{C}$.

Since burial depth was not the main reason for the observed differences in mineralogy, it follows that the diagenetic transformations in the Fe-Ni ore in Agios Ioannis were triggered by a different geochemical environment. In order for abundant chlorite to form at the expense of smectite a) there must be abundant $\mathrm{Al}$ in the system and b) Fe-smectite must be destabilized. Iron in nontronite and ferruginous montmorillonite can be readily reduced with simultaneous change from trans-vacant to cis-vacant configuration (Manceau et al., 2000; Stucki, 2006). After deposition and burial of the smectite-bearing sediments the Eh decreases with depth and the depositional environment gradually changes from aerobic at the sea floor, to suboxic and finally anaerobic at shallow depths close to the sea floor, even within the area affected by storm reworking (Taylor \& Curtis, 1995). This decrease of Eh may well cause reduction of Fe (Rozenson \& Heller-Kallai, 1978) and destabilize Fe-rich smectite.

The presence of abundant Al, must be looked for in the source material which was deposited in the karstic cavities along with the weathered lateritic mantles. There is evidence for deposition of bauxitic material in the nearby Fe-Ni deposit of Nissi (Andoniades \& Vgenopoulos, 1987). The main Al-oxyhydroxide in the deposit of Nissi is boehmite, associated with hematite, kaolinite and lesser gibbsite. The clayey horizon of Agios Ioannis contains only gibbsite (Fig. 6), the presence of which is attributed to diagenetic mobilization of Al. Aluminum can be mobilized either during dissolution of kaolinite or during conversion of Al-bearing goethite to hematite. Aluminium substitution in goethite - detected by XRD on the basis of (111) reflection - was estimated to be ca $13 \mathrm{~mol} \%$ (Skarpelis, 2005). However, scarce kaolinite has been reported in Agios Ioannis deposit (Alevizos, 1997) and its limited abundance cannot explain the predominance of chlorite. In contrast, the Fe-Ni deposits contain mainly hematite, whereas the original weathered lateritic profiles are expected to have been goethite-rich. Hence transformation of goethite to hematite during diagenesis is a plausible explanation as a source of Al. The lack of a similar Al-source in the lateritic profiles, which nevertheless contain both goethite and hematite, is attributed to the erosion of the uppermost goethite-rich horizons of the lateritic profile (ferruginous zone) which was transported and deposited in the karstified Jurassic limestones.

Finally, the presence of Fe-poor illite and mixed layer I/S is another interesting observation, which is not compatible with the geochemical characteristics of the studied sediments. The fact that these 
phases are not widespread in the Fe-Ni sediments strongly indicates that they are diagenetic. Authigenic illite is a common diagenetic phase in argillaceous sediments (Meunier, 2005 and references therein). Both phases may have been formed at the expense of precursor Al-rich phyllosilicates such as kaolinite with supply of $\mathrm{K}$ from sea water. This specific topic is currently under investigation.

\section{Conclusions}

The sedimentary Fe-Ni deposit of Agios Ioannis in Lokris contains Fe-smectite as a main clay mineral phase along with Fe-chlorite. It seems therefore that Fe-rich smectite is a widespread mineral in the Fe-Ni deposits of the broader Lokris area. Although clastic grains of chlorite have been recognized in the past by previous workers, the majority of chlorite is diagenetic and has formed at the expense of smectite via a R0 mixed layer chlorite/smectite with $>80 \%$ chlorite layers. The source of Al was probably Al-goethite which was converted to hematite after burial.

The lateritic profiles recognized in the broader Lokris area, have a different mineralogical assemblage and consist mainly of Fe-rich smectite (nontronite and/or ferruginous montmorillonite). The lack of authigenic Fe-chlorite in these lateritic profiles is attributed to the erosion of the higher lateritic horizons, which contained abundant Al-goethite. It is not known if these diagenetic mineralogical transformations were associated with mobilization of $\mathrm{Ni}$ and $\mathrm{REE}$ which has been reported in several Fe-Ni deposits and has been considered as epigenetic (Valeton et al. 1987; Maksimovic et al. 1993).

\section{Acknowledgments}

The authors would like to thank GMMSA LARKO for their permission to collect samples from the underground works of Agios Ioannis mine.

\section{References}

Augustithis, S.S., 1962. Mineralogical and Geochemical Changes in the Diagenetic and Post-Diagenetic Phases of the Ni-Cr-Iron Oolitic Deposit Larymna/Lokris, Greece. Chemie der Erde 22, 5-17.

Albandakis, N. 1974. The nickeliferous Fe-ores of Lokris and Euboia. Metal. Mining Annals, 19, 1-41 (in Greek).

Albandakis, N. 1984. Ni-minerals in the deposits of the Sub-Pelagonian zone. Mineral Wealth, 31, 9-32 (in Greek).

Alevizos, G. 1997. Mineralogy, geochemistry and genesis of sedimentary nickeliferous Fe-ores of Lokris (Central Greece). Unpubl. Ph.D Thesis, Tech. Univ. Crete, Greece, 245 p (in Greek).

Andoniades, P.A. \& Vgenopoulos, A.G. 1987. Study of the nickeliferous bauxitic laterite of the area N. Kokkino-Lokris. Metal. Mining Annals, 65, 51-60.

Andoniades, P.A. \& Vgenopoulos, A.G. 1989. Some aspects of the genesis of Ni-Fe-Lateritic ore deposits at Pissona and Katsikiza in the islad of Euboea, Greece. In: Augustithis, S.S. (ed) Metallogeny of basic and ultrabasic rocks (regional presentations), Theophrastus Publications, Athens, 519-531.

Apostolikas, A.G. 2007. The Fe-Ni ore deposit of Kopais Basin, Boiotia Prefecture. Unpubl. Ph.D Thesis, Technical University of Crete, Greece, 179 p (in Greek).

Chamley, H. 1989. Clay Sedimentology. Springer Verlag, Berlin, 623 p.

Chang, H.K., Mackenzie, F.T. \& Schoonmaker, J. 1986. Comparisons between the diagenesis of dioctahedral and trioctahedral smectite, Brazilian offshore basins. Clays Clay Miner., 34, 407-23.

Eliopoulos, D.G. \& Economou-Eliopoulos, M. 2000. Geochemical and mineralogical characteristics of 
Fe-Ni- and bauxitic-laterite deposits of Greece. Ore Geol. Rev., 16, 41-58.

Gates, W.P. 2005. Infrared spectroscopy and the chemistry of dioctahedral smectites. In: Kloprogge J.T. (ed) The Application of Vibrational Spectroscopy to Clay Minerals and Layered Double Hydroxides, CMS Workshop lectures, 13, 125-168.

Hower, J., Eslinger, E.V., Hower, M.E. \& Perry, E.A. 1976. Mechanism of burial metamorphism of argillaceous sediments. Geol. Soc. Amer. Bull., 87, 725-737.

Maksimovic,Z., Skarpelis, N. \& Panto, G. 1993. Mineralogy and geochemistry of the rare earth elements in the karstic nickel deposits of Lokris area, Greece. Acta Geol. Hungarica, 36, 331-342.

Manceau, A., Drits, V.A., Lanson, B., Chateigner, G., Wu, J., Huo, D., Gates, W.P. \& Stucki, J.W. 2000. Oxidation-reduction mechanisms of iron in dioctahedral smectites. I. Structural chemistry of oxidized reference nontronites. Amer. Mineral., 85, 133-152.

McCarty, D.K., Sakharov, B.A. \& Drits, V.A. 2008. Early diagenesis in Gulf Coast sediments: new insights from XRD profile modeling. Clays Clay Miner., 359-379.

Meunier, A. 2005. Clays. Springer-Verlag, Berlin, 472 p.

Moore, D.M. \& Reynolds, R.C. Jr 1997. X-Ray Diffraction and the Identification and Analysis of Clay Minerals, $2^{\text {nd }}$ ed. Oxford, New York, 378 p.

Rosenberg, F. 1984. Geochemie und Mineralogie lateritischer Nickel- und Eisenerze in Lokris und auf Euböa, Griechenland. Unpubl. Ph.D Thesis, Univ. Hamburg, Germany, 129 p.

Rozenson, I. \& Heller-Kallai, L. 1978. Reduction and oxidation of $\mathrm{Fe}^{3+}$ in dioctahedral smectites-III. Oxidation of octahedral iron in montmorillonite. Clays Clay Miner., 26, 88-92.

Siegl, W. 1954. Mineralogische Untersuchung der Eisenertze von Lokris und Skyros. I.G.S.R., Athens, 116-134.

Skarpelis, N. 1997. Eocene nickel laterite deposits in Greece and Albania. In: Papunen H. (ed) Mineral Deposits: Research and Exploration. Where do they meet? A.A. Balkema, Rotterdam, 503-506.

Skarpelis, N. 1999. Lateritic weathering crusts as a source of ferruginous spheroidal particles of sedimentary nickeliferous iron ores, Greece. Bull. Acad. Serbe Sci. \& Arts, 39, 213-224.

Skarpelis, N. 2000. Sedimentary nickeliferous iron ores and lateritic weathering crusts in SW Balkan Peninsula: mineralogical textural relationships and genesis. Proc. $1{ }^{\text {st }}$ Conf. Greek Comm. Econ. Geol. Miner. Geoch., 398-412 (in Greek).

Skarpelis, N. 2005. Lateritization processes of ultramafic rocks in Cretaceous times: The fossil weathering crusts of mainland Greece. J. Geoch. Explor., 88, 325-328.

Srodon, J. \& Clauer, N. 2001. Diagenetic history of Lower Palaeozoic sediments in Pomerania (northern Poland), traced across the Teisseyre-Tornquist tectonic zone using mixed-layer illite-smectite. Clay Miner., 36, 15-27.

Srodon, J., Kotarba, M., Biron, A., Such, P., Clauer, N. \& Wojtowicz, A. 2006. Diagenetic history of the Podhale-Orava Basin and the underlying Tatra sedimentary structural units (Western Carpathians): evidence from XRD and K-Ar of illite-smectite. Clay Miner., 41, 751-774.

Stucki, J.W. 2006. Properties and behaviour of iron in clay minerals. In: Bergaya, F., Theng, B.K.G. \& Lagaly, G. (eds), Handbook of Clay science, Elsevier, Amsterdam, 423-475.

Taylor, K.G. \& Curtis, C.D. 1995. Stability and facies association of early diagenetic mineral assemblages: an example from a Jurassic ironstone-mudstone succession, U.K. J. Sed. Res., 65, 358-368.

Valeton, I., Biermann, M., Reche, R. \& Rosenberg, F. 1987. Genesis of nickel laterites and bauxites in Greece during the Jurassic and Cretaceous, and their relation to Ultrabasic parent rocks. Ore Geol.Rev. $2,359-404$. 